\title{
Analysis of the Russian finance connectivity
}

\author{
Valery Smirnov*, Denis Osipov, Vladimir Gurdzhiyan, Irina Soshko, Mikhail Alexandrov, \\ and Vladimir Ivanov
}

Chuvash State University, Cheboksary, Russia

\begin{abstract}
As a result of evaluation of growth rates of major commodity prices and Russian share quotes there is discovered dominating dynamics of shares of Rosneft and Urals oil futures. Assessment of dynamics of RTSI, IMOEX, S\&P500, WTI futures, USD/RUB showed IMOEX breakdown from RTSI. RTSI remained with the WTI futures, while IMOEX joined S\&P500 trend. As a result of neural network analysis of importance of global indices growth rates there is determined a condition of achievement of their maximum value - minimum growth rate of RTSI and maximum rate of FTSE100 growth. Cluster analysis of the global indices in terms of their growth rates revealed connectivity between RTSI, DJIA and US Dollar Index. Russian economy structure can't ensure direct connectivity of RTSI and DJIA. RTSI is indirectly connected to DJIA via S\&P500. The leading role in this connection belongs to US Dollar Index that largely determines the dynamics of USD/RUB and IMOEX. Cluster analysis in terms of major currencies exchange rates growth defined a USD and CNY currency basket that is acceptable for the Russian economy. Analysis of the Russian finance connectivity has sufficiently identified a basis and conditions of its existence in the context of the strengthening negative factors which bind and overburden the Russian economy with oil dependence.
\end{abstract}

\section{Introduction}

Relevance of the Russian finance connectivity analysis is determined by the demand to reveal a defining set of economic relations for the Russian economy during establishment and utilization of monetary funds in modern conditions. It is to specify a role of the finance within the scope of commodity-money relations covered by them and in the process of social reproduction and development of the Russian economy.

Chris Brooks, Evelyn Fenton, Lisa Schopohl, James Walker have determined that the number of financial researches held through the recent two decades has grown significantly, however there remain doubts regarding their coverage and usefulness for economy and society beyond academic community. They claim the individual and institutional motivation aided isolation and thus homogenity within the subject. In the papers published in the "leading" magazines more and more often they use data from the USA even if they involve researchers from various countries. Using the information obtained as a result of assessment of effect, publication models and grants they demonstrated that this narrow agenda is not

\footnotetext{
* Corresponding author: walera712006@mail.ru
} 
relevant for the segment of financial services, economy or society in general compared to other fields of research in business and management [1].

Chris Brooks, Lisa Schopohl have thoroughly studied the matter of the financial study and its institutional features through the two recent decades. Basing on the new approaches of data science they have studied the content of over 30000 published articles and found out astonishing lack of the research topics diversity and the methodology approaches used. Almost all the financial researches are done using the methods of economics and mathematics while using almost no qualitative methods or inter-disciplinary approaches. Assessing the progress of a discipline over a timespan they discovered increase of the volume of corporate finance researches and change of topics covered after the financial crisis even though these changes seem reactive and trivial but not a paradigm change. Leading financial researches are concentrated in the US elite institutions and have disproportionately strong effect based on citing. Compared to other business and management segments the citing in the field of finance is significantly shifted towards the leading magazines as far as the latter have almost twice the impact compared to lower rated magazines [2].

Avanidhar Subrahmanyam recommends the following way to understand stock markets and distinguish reliable signals that may increase capital management efficiency: (1) it is required to take at least five years of historical analysis to demonstrate that data really "works" in terms of forecasted return; (2) it is preferable that the data is separated into two sub-periods featuring reliability check in each period; (3) there shall be a substantiated economic hypothesis why this data set works; (4) one should ask questions to find out what economic force or behavioral bias prevents timely inclusion of information in the current prices; (5) it is a reasonable question to ask how mony people have access to the data [3].

Thomas Lagoarde-Segot emphasizes the qualitative changes caused by imperatives of sustainable funding within the financial function. Through a prism of critical realism he revealed the controversy that is assigned to an incorrectly interpreted social ontology in the academic finance, and determined the methodological ways to overcome these problems and to make a way to more realistic and pluralistic approach to research funding in the $21 \mathrm{st}$ century [4].

Ming Li, Saijun Shao, Qiwen Ye, Gangyan Xu, George Q. Huang have determined that business upscaling and intensification of commodity circulation in general have led to lack of capital for retail traders, especially for small and medium business entities. Taking into account the problems of small and medium business entities in terms of obtaining capital from financial institutions such as banks there emerged an alternative of logistics finance (LF) that is combination of logistics and financial services. They proposed: (1) cross-level architecture for arrangement and management of involved resources, work processes and solutions on the basis of an object-oriented methodology (OOM); (2) hybrid finite state machine-based smart contract (HFSM-SC) designed for communication and coordination with all the types of agents of LF operations during the whole life cycle. Besides that, blockchain is integrated with the customer technology to create multi-agent system (blockchain-enabled multi-agent systemBcMAS) and provision of a trusted runtime environment for autonomous and effective fulfillment of smart-contracts [5].

Florian Königstorfer, Stefan Thalmann discovered that artificial intelligence (AI) attracts more and more attention of business and society. AI introduction in commercial banking may change business processes and interaction with customers which may generate options for behavioral financing researches. Commercial banks can use AI to reduce credit losses, increase payments processing security, automate processes related to requirements observation and improve customer alignment [6]. Jessica Paule-Vianez, Raúl GómezMartínez, Camilo Prado-Román believe that market efficiency is doubted from the moment of behavioral finance occurrence [7]. Neal Maroney, Wei Wang, M. Kabir Hassan believe 
that a traditional model of partial correction focusing on leverage evolution obstructs determination of intended corrections of capital structure [8].

Songqiao Qi, Kaijun Jin, Baisong Li, Yufeng Qian assume that in order to determine internet-finance risks there shall be used "random forest" (RF) - a general algorithm of finance classification for machine education. Results of traditional statistical methods were compared to RF and "back propagation" (BP) results. It was discovered that credit risk and personal information risk were the most important factors of internet finance development when a BP neural network was used for these risks assessment [9].

Xiaofeng Xie, Yang Yang, Jing Gu, Zongfang Zhou believe that funding structure significantly influences the chain reaction effect that rises as the share of trade credits funding extends [10].

Xinhan $\mathrm{Xu}$, Xiangfeng Chen, $\mathrm{Fu}$ Jia, Steve Brown, Yu Gong, Yifan $\mathrm{Xu}$ assume that supply chain finance (SCF) is an effective method to reduce funding costs and to increase efficiency and productivity of funding [11].

Egle Vaznyte, Petra Andries have a theory that entrepreneur orientation of a startup has different effect on costs and benefits related to external borrowed and share funding, and thus on use of corresponding forms of funding, and the strength of these relations depends on the industry branch risk and the stage of venture company development [12].

Sasan Bakhtiari demonstrated that state support influences companies by increasing their tendency to search for funding and furthermore by increasing their tendency to obtaining funding. Effect scale changes depending on the form and quantity of support obtained from state [13]

So, indeed the total number of financial researches through the previous two decades significantly increased, but there is seen a lack of understanding of substantial issues of finance use in the modern economy.

\section{Methods}

For the purpose of analysis of the Russian finance content we use the methods of statistical, neural and cluster analysis including processing of statistical figures, their systematizing and representation in the form of diagrams and tables. Statistical data processing is done using IBM SPSS Statistics, while tables, diagrams and graphs were done in IBM SPSS Statistics and MS Excel.

Statistical analysis if a method of acquisition, studying and representation of large volumes of data by signs and interrelations of data, correlation interrelations of spatial and time rows of values observing the research methodology $[14,15]$.

Neural network analysis allows to determine the laws of changes of objects or phenomena by building neural networks. It appears in determination of significant financial relations and revealing a basis of the Russian finance existence.

Application of cluster analysis is determined by complementation of the probability understanding of casuality with the relatedness of changes of the assessed figures. Cluster analysis systematizes date containing information about sampling of objects and arranges the research objects in comparatively homogenous groups thus allowing to develop classification of researched objects or phenomena, to determine the major schemes of their grouping and to formulate hypotheses [16].

Hypotheses formulated using neural network and cluster analysis would allow to arrange the basis of the Russian finance existance and use it for management decision making. 


\section{Results and discussion}

An information substrate for the content analysis of the Russian finance is the news and analytics of the Forex currency market, stock and commodities markets at ProFinance.Ru, TradingView, Moscow Exchange Group based on the date from the World bank, the International Monetary Fund, Intercontinental Exchange, the Central Bank and the Federal service for State Statistics of the Russian Federation.

The basis for content analysis of the Russian finance is the estimation of growth rates of prices for the basic commodities and quotes of Russian stock and the changes of RTSI, IMOEX, S\&P500 indexes, WTI futures, USD/RUB.

As a result of evaluation of growth rates of major commodity prices and Russian share quotes there is discovered dominating dynamics of shares of Rosneft and Urals oil futures. Rosneft is the leader of the Russian oil industry and the largest public oil and gas corporation of the world. The major shareholder $(40.4 \%$ of stock) is ROSNEFTEGAZ AO that completely belongs to the government, $19.75 \%$ of shares belongs to BP Russian Investments Limited (Private Limited Company, United Kingdom), 18.93\% of shares belong to QH Oil Investments LLC (Qatar) and one share belongs to the government represented by the Federal agency for state property management. Urals is a sort of oil rich with sulfur $(\sim 1.3 \%)$. The principal producers of Urals oil are Rosneft, Bashneft, Lukoil, Surgutneftegaz, Gazprom neft and Tatneft.

Assessment of dynamics of RTSI, IMOEX, S\&P500, WTI futures, USD/RUB showed IMOEX breakdown from RTSI. RTSI remained with the WTI futures, while IMOEX joined S\&P500 trend. It needs to be understood that within the existing structure of the Russian economy the ruble index of IMOEX may align to the trend of USD S\&P500 index only due to growth of USD exchange rate in relation to RUB. In this regards the global economy digitalization and introduction of crypto currencies to a financial system doesn't have significant effect on IMOEX dynamics.

RTSI (RTS Index - Russian trading system) is an aggregate indicator calculated on the basis of a particular set of key shares (Sber, Lukoil, Gazprom, Rosneft, X5 Retail Group, Norilsk nickel, etc.) and characterizes the state of Russian stock market. About $45 \%$ of companies included in RTSI belong to oil and gas industry, about $19 \%$ belong to financial segment and about $17 \%$ belong to metals mining and processing. RTSI reflects the current aggregate market capitalization (in USD) of shares of a particular list of emitents in relative free-float units (share of free-floating stock) expressed in USD.

IMOEX (Moscow Exchange Group) is the major indicator of the Russian financial market condition and it includes 50 most liquid shares of the largest and dynamically growing companies belonging to key industries of economy. Quantity and content of shares may change periodically. Shares of companies belonging to the following industries have the largest weight: energy resources - about $45 \%$; finance $-18 \%$; metals and mining $-17 \%$; consumer segment - $11 \%$; transport - 2\%; telecommunications - 3\%; electric power engineering - 3\%. IMOEX includes 42 shares of the largest and most prospective Russian companies belonging to economy key segments, and among those the following are residents: Rosneft, Gazprom, VTB, Sber, Lukoil, Norilsk nickel, Polus, Tatneft, Magnit, Rostelekom, MTS, Surgutneftegaz. IMOEX is calculated in real time in RUB as a weighted average of capitalization of regular and privileged stock.

S\&P500 (Standard \& Poor's 500 index) is a stock exchange index including 505 selected public companies traded at the US stock exchanges and having largest capitalization. Shares of all the companies included in S\&P500 are traded at the largest US stock exchanges such as New-York Stock Exchange and NASDAQ. S\&P500 index competes with Dow Jones Industrial Average Index (DJCFD) in terms of popularity. The index consists of the largest companies (without privately owned companies) which minimum trade volume is over 
250000 shares per month, but these companies differ a lot from each other in terms of capitalization. 10 largest components of S\&P500 index as of February 2020: Microsoft Corporation, Apple, Amazon, Facebook, Berkshire Hathaway Class B, Alphabet class c, Alphabet class a, JPMorgan Chase, Johnson \& Johnson, Visa.

Capability of IMOEX ruble index to move within the trend of USD index S\&P500 is related to the potential of the Moscow Exchange that was founded in December 2011 as a result of a merger of the two main Russian stock exchange groups - MMVB group (founded in 1992) ans RTS group (founded in 1995). A vertically integrated structure that emerged as a result of merger allowed to trade all the main categories of assets: at the stock market trading shares, federal loan bonds, regional and corporate bonds, sovereign and corporate Eurobonds, depositary receipts, investment shares, mortgage participation certificates and exchange traded funds (ETF); at the derivatives market - futures contracts for indices ( Moscow Exchange Index, RTS index, RVI volatility index), futures for Russian and foreign stocks, federal loan bonds and Russia-30 Eurobonds, currency pairs, interest rates, contracts for precious metals (gold, silver, platinum, palladium, copper); oil and sugar futures; option contracts for some of these futures; at foreign currency market - currencies: US dollar (USD), Euro (EUR), Chinese Yuan (CNY), British Pound (GBP), Hong Kong Dollar (HKD), Ukrainian Hryvnia (UAH), Kazakh Tenge (KZT) and Belarusian Ruble (BYR); at money market - repo service (repo with CCP, inter-dealer repo, direct repo with the Bank of Russia, repo with a collateral management system), etc., in addition, there are available deposit and credit operations organized by the Bank of Russia, the Pension Fund of Russia, the Federal Treasury of Russia, Vnesheconombank, etc.

The dominating dynamics of Rosneft shares quotations and Urals futures makes RUB to loose value to keep the leading economy industries working at the US growth rates.

As a result of neural network analysis of importance of global indices growth rates there is determined a condition of achievement of their maximum value - minimum growth rate of RTSI and maximum rate of FTSE100 (Financial Times Stock Exchange) growth.

Cluster analysis of the global indices in terms of their growth rates (Table 1) revealed connectivity between RTSI, DJIA (Dow Jones Industrial Average) and US Dollar Index. In its turn DJIA is related to S\&P500.

Table 1. Neural network analysis of the importance of the rates of gain of world indices, 2015-2020.

\begin{tabular}{|c|c|c|c|c|}
\hline Index & \multicolumn{3}{|c|}{ Importance, \% } & Average, $\%$ \\
\hline RTSI & 43.5 & 25.2 & 14.1 & 27.6 \\
\hline DJIA & 100.0 & 66.3 & 76.8 & 81.1 \\
\hline S\&P500 & 23.6 & 44.7 & 85.8 & 51.4 \\
\hline Nasdaq Composite, NASD_COMP & 52.9 & 8.5 & 78.7 & 46.7 \\
\hline Nasdaq 100, NASD100 & 17.3 & 57.3 & 55.7 & 43.4 \\
\hline FTSE100 & 30.9 & 80.7 & 100.0 & 70.5 \\
\hline DAX & 41.6 & 100.0 & 31.8 & 57.8 \\
\hline AEX & 38.5 & 17.9 & 82.5 & 46.3 \\
\hline CAC40 & 47.7 & 25.1 & 60.2 & 44.3 \\
\hline SMI & 31.1 & 72.9 & 78.2 & 60.7 \\
\hline US Dollar Index & 14.0 & 26.0 & 30.0 & 23.3 \\
\hline Me, \% & 38.5 & 44.7 & 76.8 & 46.7 \\
\hline
\end{tabular}

Note. Multilayer perceptron, batch training.

Source: calculated using "IBM SPSS Statistics" according to ProFinance.Ru data Copyright (C) 1995 - 2020 ProFinance.ru. https://www.profinance.ru.

Russian economy structure can't ensure direct connectivity of RTSI and DJIA. RTSI is indirectly connected to DJIA via S\&P500 (Table 2). 
Table 2. Complex clusters of world indices in terms of their rates of gain, 2015-2020.

\begin{tabular}{|c|c|c|}
\hline \multicolumn{2}{|c|}{ Cluster } & Square of the Euclidean distance \\
\hline \multirow{2}{*}{ RTSI } & DJIA & 1954.366 \\
\cline { 2 - 3 } & US Dollar Index & 2185.049 \\
\hline \multirow{2}{*}{ DJIA } & S\&P500 & 94.783 \\
\cline { 2 - 3 } & Nasdaq Composite, NASD_COMP & 366.702 \\
\cline { 2 - 3 } & FTSE100 & 1122.631 \\
\hline \multirow{2}{*}{ FTSE100 } & SMI & 461.832 \\
\cline { 2 - 3 } & DAX & 513.939 \\
\hline \multirow{2}{*}{ DAX } & CAC40 & 193.319 \\
\cline { 2 - 3 } & AEX & 301.666 \\
\hline
\end{tabular}

Note: Hierarchical cluster analysis - the average distance between clusters, the square of the Euclidean distance.

Source: calculated using "IBM SPSS Statistics" according to ProFinance.Ru data Copyright (C) 1995 - 2020 ProFinance.ru. https://www.profinance.ru.

The leading role in this communication belongs to US Dollar Index that largely determines the dynamics of USD/RUB and IMOEX. This phenomenon is confirmed by the importance of USD/RUB growth rates revealed by neural network analysis (Table 3). Synchronity of USD/RUB and EUR/RUB growth rates allows to influence the exchange rates of the main currencies, Gold and XBT.

Table 3. Neural network analysis of the importance of the rates of gain of the exchange rate, also Gold and XBT, against the ruble, 2015-2020.

\begin{tabular}{|c|c|c|c|c|}
\hline $\begin{array}{c}\text { Currency to ruble exchange rates at the inter- } \\
\text { bank currency market }\end{array}$ & \multicolumn{3}{|c|}{ Importance, \% } & Average, \% \\
\hline USD/RUB & 49.0 & 84.3 & 100.0 & 77.8 \\
\hline EUR/RUB & 100.0 & 84.8 & 23.1 & 69.3 \\
\hline JPY/RUB & 60.2 & 100.0 & 26.0 & 62.0 \\
\hline CNY/RUB & 45.8 & 73.3 & 97.3 & 72.2 \\
\hline Gold/RUB & 42.3 & 74.5 & 55.5 & 57.5 \\
\hline XBT/RUB & 31.4 & 51.9 & 19.8 & 34.4 \\
\hline Me, \% & $\mathbf{4 7 . 4}$ & $\mathbf{7 9 . 4}$ & $\mathbf{4 0 . 7}$ & $\mathbf{6 5 . 7}$ \\
\hline
\end{tabular}

Note. Multilayer perceptron, batch training.

Source: calculated using "IBM SPSS Statistics" according to ProFinance.Ru data Copyright (C) 1995 - 2020 ProFinance.ru. https://www.profinance.ru.

Cluster analysis in terms of major currencies exchange rates growth (Table 4) defined a USD and CNY currency basket that is acceptable for the Russian economy.

Table 4. Complex currency cluster, a basket of currencies by the rates of gain of the exchange rate, 2015-2020.

\begin{tabular}{|c|c|c|}
\hline \multicolumn{2}{|c|}{ Cluster } & Square of the Euclidean distance \\
\hline USD/RUB & CNY/RUB & 89.136 \\
\cline { 2 - 3 } & EUR/RUB & 433.465 \\
\cline { 2 - 3 } & JPY/RUB & 511.927 \\
\cline { 2 - 3 } & Gold/RUB & 1048.958 \\
\cline { 2 - 3 } & XBT/RUB & 36402.620 \\
\hline
\end{tabular}

Note: Hierarchical cluster analysis - the average distance between clusters, the square of the Euclidean distance.

Source: calculated using "IBM SPSS Statistics" according to ProFinance.Ru data Copyright (C) 1995 - 2020 ProFinance.ru. https://www.profinance.ru.

Thus the natural resources-based nature of the Russian economy defines domination of dynamics of Rosneft shares and Urals futures. The necessity to change this situation in order 
to keep the leading industries of the Russian economy growing at the US rates level (DJIA) makes RUB to constantly loose value. This phenomenon makes the MOEX ruble index move within the S\&P500 US dollar index trend and defines filling of USD and CNY basket. There shall be distinguished the following provision - monetary base (within the narrow sense) increased from by $60.7 \%$ from $8298.5 \mathrm{bln}$. RUB as of $11 / 01 / 2014$ to $13334.5 \mathrm{bln}$. RUB as of $11 / 01 / 2020$ and the International reserves of the Central Bank of the Russian Federation increased by $63.6 \%$ from $357.6 \mathrm{bln}$. USD As of $07 / 31 / 2015$ to $584.9 \mathrm{bln}$. USD As of $11 / 20 / 2020$. The difference of $2.9 \%$ is the maximum possible growth rate of the Russian economy.

As a result of analysis of the Russian finance connectivity there has been revealed an imitation of the Russian economy liberation from the natural resources dependency due to movement within the MOEX index and S\&P500 index trend. This movement has negative effect related to devaluation of RUB and limitation of the internal investment growth potential of the Russian economy due to connecting of monetary base with the volume of International reserves of the Central Bank of the Russian Federation thus setting a 3\% limit of GDP growth.

\section{Conclusions}

Analysis of the Russian finance connectivity revealed targeting of economic relations in the context of preservation of the natural resources nature of the Russian economy. This provision acts as a finished basis of the Russian finance existence distinguishing domination of dynamics of Rosneft shares and Urals futures as condition of the Russian economy existence.

In order to keep the conditions of the Russian economy existence there is maintained movement within the MOEX index trend together with S\&P500 index by means of RUB devaluation and connection of monetary base with the International reserves of the Central Bank of the Russian Federation and by means of ignoring the crypto currencies potential.

\section{References}

1. C. Brooks, E. Fenton, L. Schopohl, J. Walker, Critical Perspectives on Accounting 58, 24 (2019)

2. C. Brooks, L. Schopohl, The British Accounting Review 50(6), 615 (2018)

3. A. Subrahmanyam. Borsa Istanbul Review 19(4), 283 (2019)

4. T. Lagoarde-Segot, Research in International Business and Finance 47, 1 (2019)

5. M. Li, S. Shao, Q. Ye, G. Xu, G. Q. Huang, Robotics and Computer-Integrated Manufacturing 65, 101962 (2020)

6. F. Königstorfer, S. Thalmann, J. of Behavioral and Experimental Finance 27, 100352 (2020)

7. J. Paule-Vianez, R. Gómez-Martínez, C. Prado-Román, European Research on Management and Business Economics, 26(2), 71 (2020)

8. N. Maroney, W. Wang, M. K. Hassan, J. of International Money and Finance 90, 204 (2019)

9. S. Qi, K. Jin, B. Li, Y. Qian, J. of Computational and Applied Mathematics 369, 112630 (2020)

10. X. Xie, Y. Yang, J. Gu, Z. Zhou, Environmental Research 184, 109356 (2020) 
11. X. Xu, X. Chen, F. Jia, S. Brown, Y. Gong, Y. Xu. Int. J. of Production Economics, 204, 160 (2018)

12. E. Vaznyte, P. Andries, J. of Business Venturing 34, 3, 439-458 (2019)

13. S. Bakhtiari, International Review of Economics \& Finance 72, 59 (2021)

14. V. V. Smirnov, V. L. Semenov, E. N. Kadyshev, T. V. Talanova, A. N. Zakharova, N. G. Gubanova. Proceedings of the 35th International Business Information Management Association Conference (IBIMA), 3736 (2020)

15. V.V. Smirnov, D.G. Osipov, A.A. Babaeva, E.V. Grigorieva, E.F. Perfilova, Advances in Economics, Business and Management Research. Proceedings of the 1st International Scientific Conference (2019)

16. V. V. Smirnov, A. N. Zakharova, T. V. Talanova, A. G. Abramova, S. A. Petunova, I. B. Getskina, M. N. Yaklashkin. The Problem of Youth Unemployment and Entrepreneurship. Proceedings of the 35th International Business Information Management Association Conference (IBIMA), 7741 (2020) 